\title{
Seasonal Bioaccumulation of Copper in Guppy, Poecillia reticulata [Peters] with Characterization of the Hydrophohic Fraction of Its Octanol - Water Emulsion
}

\author{
Rachelle C. Cañete, Lora Mae G. Villegas, Josephine M. Castañares* \\ Chemistry Analytical and EnvironmentaL Section II (ChAnELS II) \\ Department of Chemistry, University of San Carlos, Cebu City 6000, Philippines
}

In this study, copper was seasonally determined in water, sediment and guppy fish (Poecilia reticulata) from Butuanon River, which is an important water source for drinking and irrigation in Metro Cebu, using Flame Atomic Absorption Spectroscopy (FAAS).

Results revealed that $\mathrm{Cu}$ levels in water were within the acceptable standard of DENR DAO 34 (1990) while it exceeded the maximum allowable limit of $100 \mathrm{ppm}$ for sediments in dry season. Only guppies in station 1 exceeded the FAO/WHO (1989) acceptable limit of $30 \mathrm{mg} / \mathrm{kg}$. Bioaccumulation factor (BAF) of guppies in water was calculated and determined to be within the ranges $411-1675$ and $557-3735 \mathrm{~L} / \mathrm{Kg}$ for dry and wet seasons, respectively. Octanol-water partition coefficients values vary per station indicating that the form and levels of copper differ in all stations. Traces of thiodiazole were also detected in the hydrophobic fraction of the octanol-water emulsion.

High BAF suggest that guppies have a high potential of accumulating the contaminant from water and that it can be used as a bioindicator in rivers (USEPA, 2007). The low $\mathrm{BAF}$ with respect to sediment implies that sediments serve as metal sequesters making it non-bioavailable. Moreover, there is an anthropogenic indication of copper introduction in all stations attributable to agricultural sources.

Keywords: bioaccumulation factor, octanol-water partition coefficient, Poecilia reticulata, copper pollution, Butuanon River, bydrophobic fraction

\section{INTRODUCTION}

Butuanon River, running through two emerging cities of Cebu and Mandaue, Philippines is used to be considered as a source of surface water. These waters are usually tapped by Metro Cebu Water District (MCWD) for drinking purposes following intensive purification. Due to rapid urbanization and industrialization in both

\footnotetext{
*Author to whom correspondence should be addressed; email: jmcastanares@yahoo.com
} 
cities, the river has become the principal disposal site for untreated domestic sewage, industrial discharges and agricultural wastes. A number of studies also indicated the alarming rate of river degradation caused by a complex mixture of pollutants from various sources (Nazareno, 2000; Muego, 2006; Mendoza and Suico, 1995; Oquiñena, 2012). The river also faces heavy metal pollution problems with the highest concentrations for copper, lead and zinc were recorded (Mendoza and Suico, 1995; Nazareno, 2000).

Previous studies specifically on copper revealed that its distribution in water and sediments in Butuanon River are as follows: (i) Cu level was critical based on the DENR Water Quality Criteria (Mendoza, 1993); (ii) chemical speciation of copper in the sediment showed that a major portion is found in the residual fraction (Suico, 1997); and (iii) $\mathrm{Cu}$ bioaccumulated in Catfish (Clarias macrocephalus) is high with respect to sediment (Oquiñena, 2012). Although this metal is a required element, high concentrations appear to be toxic to freshwater organisms (Sanchez et al., 2005).

Fishes are notorious for their ability to concentrate heavy metals and play important role in human nutrition; they need to be carefully screened to ensure that unnecessary high level of some toxic trace metals are not being transferred to man through fish consumption (Adenivi and Yusuf, 2007). As heavy metals cannot be degraded, they are deposited, assimilated or incorporated in water, sediment and aquatic animals (Linnik and Zubenko, 2000) and thus, causing heavy metal pollution in water bodies (Malik et al., 2010). Therefore, heavy metals can be bioaccumulated via the food chain and finally assimilated by human consumers resulting in health risks (Agah et al., 2009). As a consequence, fishes are often used as indicators of heavy metal contaminations in the aquatic ecosystem because they occupy high tropic levels and because they are an important food source (Agah et al., 2009; Blasco et al., 1998). Hence, the present study was aimed to determine the ability of guppy fish (Poecilia reticulata, Peters) collected from the Butuanon River at Metro Cebu, Philippines to indicate level of copper contamination in water and sediments.

\section{METHODOLOGY}

Description of Study Area. Butuanon River is a 23-kilometer water body which originates in the mountain area around Metro Cebu and eventually discharges into Mactan Channel as shown in Figure 1. Approximately 10kilometer length of the river is crossing Metro Cebu area, most significantly the heavily industrialized and densely populated areas of Mandaue City.
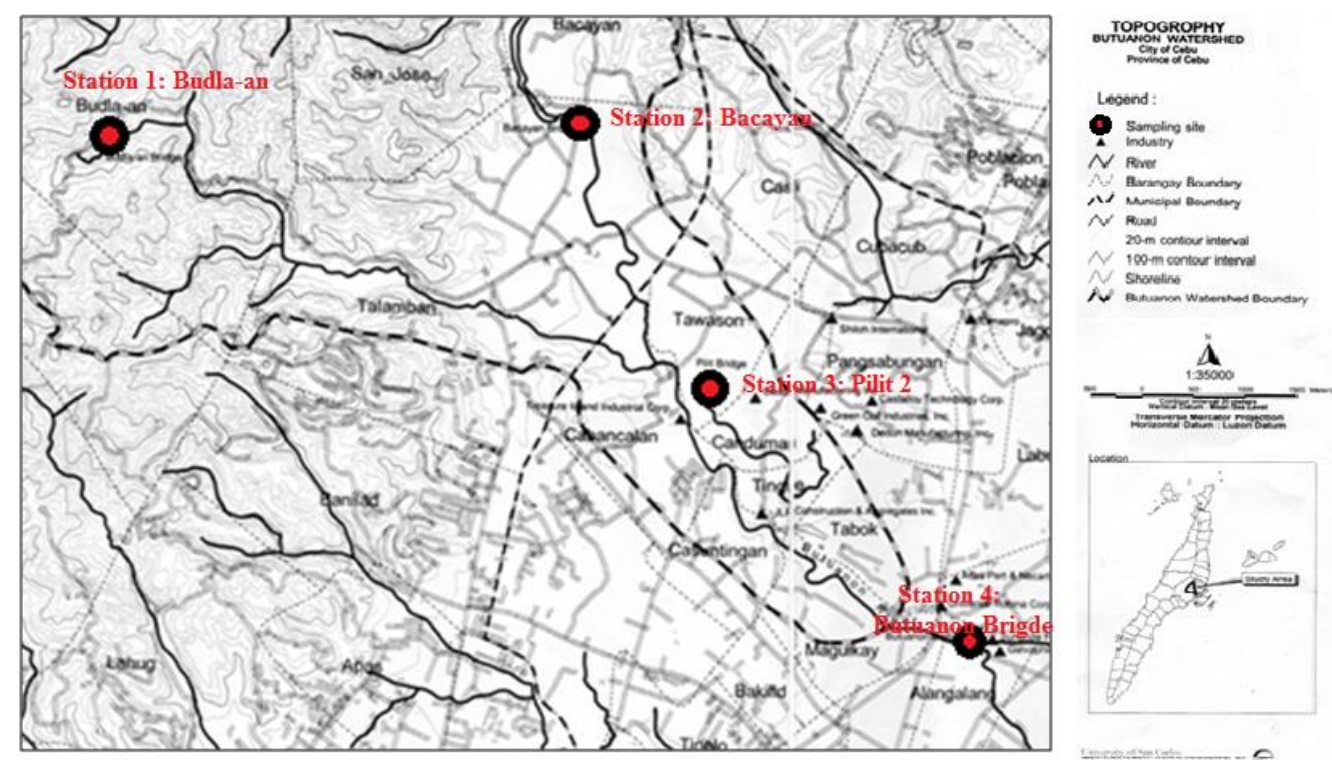

Figure 1. Butuanon River Watershed and River System. 
Sampling Design. The sampling for water, sediment and guppy fish was carried out in May and July 2012 representing both the dry and wet seasons, respectively. Four sampling stations were chosen to represent the upstream, upper midstream, lower midstream and downstream of the river. Figure 1 shows the three sampling stations while description of the stations and its coordinates are tabulated in Table 1.

Table 1. Description of Sampling Stations and Its GPS Coordinates.

\begin{tabular}{|c|c|c|}
\hline Station & Coordinates & Description \\
\hline Station 1 & $\begin{array}{l}10^{\circ} 22^{\prime} 44^{\prime \prime} \mathrm{N} \\
123^{\circ} 53^{\prime} 05^{\prime \prime} \mathrm{E}\end{array}$ & Upstream site. Mainly domestic and agricultural lands \\
\hline Station 2 & $\begin{array}{l}10^{\circ} 22^{\prime} 50^{\prime} \mathrm{N} \\
123^{\circ} 55^{\prime} 09^{\prime} \mathrm{E}\end{array}$ & $\begin{array}{l}\text { Upper midstream site. Domestic and industrial effluents; } \\
31 \% \text { gas station and services, } 16 \% \text { aluminum, } \sim 7-8 \% \\
\text { furniture, mix concrete, food processing, steel, paint, etc. }\end{array}$ \\
\hline Station 3 & $\begin{array}{l}10^{\circ} 21^{\prime} 43^{\prime \prime} \mathrm{N} \\
123^{\circ} 55^{\prime} 34^{\prime \prime} \mathrm{E}\end{array}$ & $\begin{array}{c}\text { Lower midstream site. Predominantly industrial effluents; } \\
\text { food processing } 32 \% \text {, gas station and services } 14 \%, 12 \% \\
\text { furniture }\end{array}$ \\
\hline Station 4 & $\begin{array}{l}10^{\circ} 20^{\prime} 36^{\prime \prime} \mathrm{N} \\
123^{\circ} 56^{\prime} 44^{\prime \prime} \mathrm{E}\end{array}$ & $\begin{array}{c}\text { Downstream site. Industrial and domestic effluents } \\
\text { including a large squatter area; } 23 \% \text { food processing } \\
\text { industry, } 18 \% \text { furniture, } 9 \% \text { galvanized iron industry, } \\
\text { gasoline station, and ready mixed concrete }\end{array}$ \\
\hline
\end{tabular}

Collection of Water, Sediment and Fish Samples and Copper Analysis. Dissolved oxygen, stream flow, $\mathrm{pH}$ and temperature were determined on site. Twenty liters of composite water sample was collected in each station and placed in a polyethylene bottle rinsed with $50 \%$ (v/v) $\mathrm{HNO}_{3}$ and chilled upon transport. The samples were then digested and analyzed for copper in triplicates using the standard methods of APHAAWWA (1989) by Flame Atomic Absorption Spectroscopy (FAAS) coupled with multiple standard addition (MSA) technique. Recovery tests were also performed for each station.

Quadrant sampling was used in each station using a core sampler. The samples were then contained in polyethylene bags and chilled during transport to the laboratory. The sediment samples were air-dried until parched, sieved at $0.002 \mathrm{~mm}$, ground using mortar and pestle, ball-milled and oven dried at $110{ }^{\circ} \mathrm{C}$ to constant weight. Oven-dried sediments were digested using the Acid Digestion Method of Sediments by EPA 3050B and analyzed for copper using FAAS via MSA. The $\mathrm{pH}$ of the sediment was also determined on site.

A total of 30-40 fishes were randomly collected from each sampling stations using a fish net. The washed fish samples were then packed in plastic bag, labeled, and transported in ice boxes to the laboratory. The fish samples were washed again with distilled water and oven-dried at $110{ }^{\circ} \mathrm{C}$ until constant weight. Fishes were pooled to obtain about $0.25-0.35 \mathrm{~g}$ dry weight of fish sample for microwave digestion based on AOAC Method 999.10 with $1 \mathrm{~mL}$ of $30 \% \mathrm{H}_{2} \mathrm{O}_{2}$ and $7 \mathrm{~mL}$ concentrated $\mathrm{HNO}_{3}$. The microwave digested samples were analyzed for copper with FAAS coupled with external calibration method. Recovery test was also conducted.

$\boldsymbol{K}_{\text {ow }}$ and FTIR. The shake-flask method, as reported (Turner and Mawji, 2005; Turner and Williamson, 2005), was used: Six 5-mL samples of filtered river water were pipetted into a $50-\mathrm{mL}$ centrifuge tubes. To the three tubes, $5 \mathrm{~mL}$ of reagent-grade octanol were added and the screw capped contents were gently shaken for 14-16 hours at room temperature. The resulting organic and aqueous phases were separated by centrifugation at $3600 \mathrm{rpm}$ for 30 minutes. Four $\mathrm{mL}$ of the aqueous phase of each aliquot were then pipetted into clean tubes and the contents analyzed at the same time as the 
content of the remaining three screw-capped tubes. The $\mathrm{K}_{\mathrm{ow}}$ of the river water from each station was determined from the difference in the mean concentration in the two sets of aliquots divided by the mean concentration in the aliquot extracted with octanol. The organic phase were then analyzed further using FTIR-ATR.

Statistical Treatment of Data. Statistical analyses of the experimental data were performed using GraphPad Prism Version. 6.0 Free trial version (GraphPad Software, Inc. San Diego, California). The means of the replicates and the evaluation of the significant differences among sampling sites and seasons were determined using descriptive statistics and multiple analysis of variance (MANOVA). Correlations between concentrations in the fish and BAF were evaluated using Pearson's $r$.

\section{RESULTS AND DISCUSSION}

Physico-Chemical Analyses. Physicochemical analyses were conducted on-site during the seasonal collection of the water samples. Table 2 shows the results for both dry and wet seasons.

Table 2. Physico-chemical Analysis of Butuanon River Water at Different Seasons.

\begin{tabular}{ccccccc}
\hline \multirow{2}{*}{ Stations } & \multicolumn{2}{c}{ Stream Flow, $\mathbf{m} / \mathbf{s}$} & \multicolumn{2}{c}{ DO, mg/L } & \multicolumn{2}{c}{ pH } \\
\cline { 2 - 7 } & Dry & Wet & Dry & Wet & Dry & Wet \\
\hline 1 & $0.307 \pm 0.13$ & $4.82 \pm 0.11$ & $5.20 \pm 0.11$ & $7.70 \pm 0.03$ & $7.95 \pm 0.03$ & $8.60 \pm 0.05$ \\
\hline 2 & $0.451 \pm 0.28$ & $2.36 \pm 0.09$ & $3.50 \pm 0.08$ & $7.70 \pm 0.05$ & $7.79 \pm 0.01$ & $8.30 \pm 0.03$ \\
\hline 3 & $0.109 \pm 0.23$ & $4.40 \pm 0.12$ & $2.10 \pm 0.05$ & $7.30 \pm 0.09$ & $8.37 \pm 0.05$ & $8.48 \pm 0.04$ \\
\hline 4 & $0.000 \pm 0.00$ & $10.68 \pm 0.07$ & 0.00 & $5.80 \pm 0.10$ & $6.63 \pm 0.05$ & $2.90 \pm 0.06$ \\
\hline
\end{tabular}

According to the DENR Administrative Order 34 (DAO 34), the $\mathrm{pH}$ range of a Class $\mathrm{D}$ type water like the Butuanon River should be $6.00-9.00$. The $\mathrm{pH}$ of the river ranges from $6.63-8.37$ in the dry season while it ranges from $2.90-7.70$ in the wet season. The results showed no significant difference $(\mathrm{p}=$ 0.0941) between $\mathrm{pH}$ and stations in both dry and wet periods. The slightly high $\mathrm{pH}$ values in Station 3 during the dry season might be attributed to sewage water discharge from surrounding areas (Malik et al., 2010). Other than in Station 4 wet season, the $\mathrm{pH}$ values recorded in this study were well within the preferred $\mathrm{pH}$ of 6.5 to 9.0 recommended for optimal fish production (PHILMINAQ, 2008).

The DO values of river water are much lower in dry season compared to the wet season. This is similar to the results of (Abowei, 2010) who reported that at high temperatures, which is usually observed in dry season, the solubility of oxygen decreases while at lower temperature (wet season), it increases. A decreasing trend was also observed from upstream station 1 down to station 4 . This means that the DO in station 4 can no longer support aquatic life.

\section{Copper in Water.}

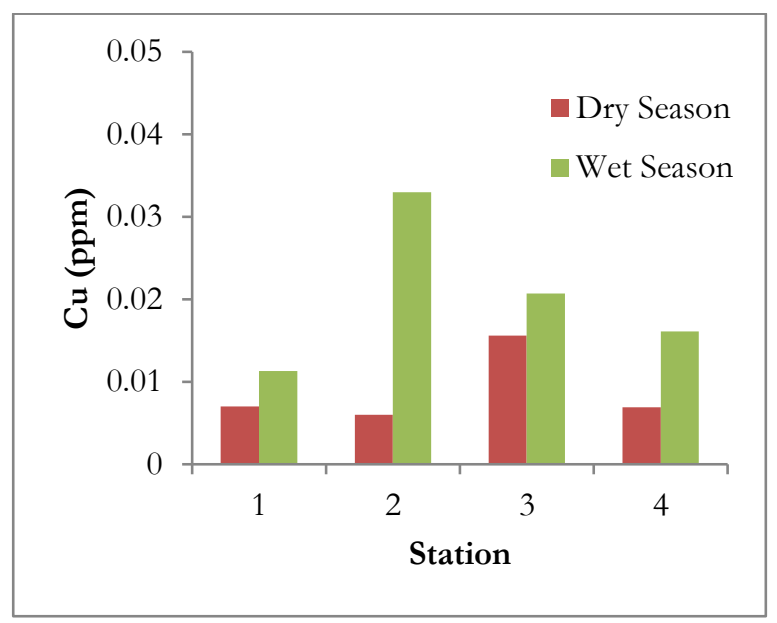

Figure 2. Copper Concentration in W ater.

The copper levels in the four sites of the Butuanon River are below the standard limit for copper which is 0.05-ppm (DENR-DAO 34). The most evident observation from Figure 2 is the high concentration of copper in the wet season compared to that of the dry season. This is in accordance to the report of 
Gaur et al. (2005) in Gomti River, India in which high concentrations of metals, like copper, were detected in water during the rainy season compared to the summer season because during the rainy season, runoff from open contaminated sites, agricultural field and industries directly comes into the river without any treatment. The upstream of the Butuanon River was characterized by the presence of large mango plantation, cut flower cultivation and extensive farming (Bongo, 1998). Further, 18 types of industries like furniture, paint and thinner production, two gas stations, two oxygen acetylene production facilities among others were located within the midstream station while 36 industries which includes thirteen food and feed manufacturers, four galvanized iron producers, three aluminum factories, an oil treatment facility among others were situated near downstream (Mandaue City Office of Sustainability and Environment, 2013).

For the wet season, Station 2, which is a semiresidential area, has the highest copper level. This may be due to the presence of the six furniture industries which may use coppercontaining preservatives for the woods. The Agency for Toxic Substances and Disease Registry (ATSDR) reported in 2004 that copper was used as preservatives for wood, leather and fabric. A carwash station is also present just above the sampling site. The rain might have washed away their coppercontaining wastes, which include gasoline, motor oil, grease, anti-freeze, and brake linings (Aksu and Donmez, 2000; Savvaidis et al., 2003). The observed decrease in copper concentration from Station 2 to Station 3 may be attributed to the dilution process due to three weather disturbances for July 2012 as recorded by PAG-ASA Mactan namely tropical storm Enteng, tropical depression Ferdie and Typhoon Gener.

The accuracy of the method was assessed using percent recovery in both dry and wet seasons. The average percent copper recovery in river water was found to be $110 \%$ which is within the National Institute of Standards and Technology (NIST) certified acceptance/ recovery range of $80 \%$ to $120 \%$ or the sample batch must be reanalyzed (Huber, 2007; Schantz and Kucklick; Hokanson, 1994).

Copper in Sediments. The copper levels in sediments were very high in both dry and wet seasons due to the above neutral sediment $\mathrm{pH}$ that favors precipitation of copper hydroxides and carbonates. These levels also exceeded the maximum allowable limit of $100 \mathrm{ppm}$ (Deparment of Environment and Natural Resources, 1990) and clearly suggest the occurrence of anthropogenic introduction of copper in the said river. The likely major source of contamination is the wide spread use of copper containing fungicides in the mango plantation and other agricultural crops at the upper portions of the river (Hokanson, 1994). Chiu-Wen Chen, et al. (2012) also concluded that the upstream agricultural and municipal wastewater discharges along the river bank are the major sources of copper pollution.

As shown in Figure 3, the copper levels in sediments during the dry season were roughly the same in Stations 1 and 3 with a slight decrease in Station 2 increased by almost 33\% in Station 4. There is no significant difference $(\mathrm{p}=0.0550)$ in sediment copper concentrations in Stations 1 to 3 between the dry and wet seasons but a significant difference $(p<0.0001)$ was observed in Station 4 which means that this is a distinct site in terms of source of copper contamination compared to Stations 1, 2, and 3.

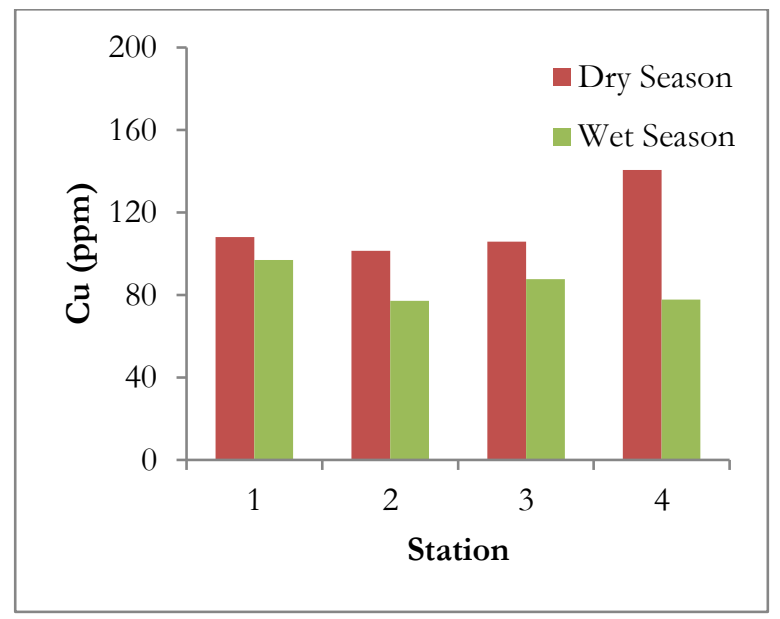

Figure 3. Copper Concentration in Sediments. 
It can also be deduced from Figure 3 that the copper in sediments during the damp season reduced in concentrations in all sampling sites. The three weather disturbances for the wet season (July 2012) caused heavy downpour as high as $78.8 \mathrm{~mm}$ and might have caused the erosion of sediments and thus transferring some of the sediment-bound copper to water.

Copper in Guppy Fish. The highest concentration of copper in guppy for dry season was in station $1(10.75 \mathrm{mg} / \mathrm{kg})$ while the lowest concentration detected was $6.14 \mathrm{mg} / \mathrm{kg}$ in Station 3. The same trend was observed for the wet season with the maximum copper level amounting to $35.08 \mathrm{mg} / \mathrm{kg}$ in station 1. This means that the $P$. reticulata can concentrate certain amount of copper exceeding those present in water but not in sediments. Further, the mean $\mathrm{Cu}$ concentrations observed in guppies in this study did not exceed the acceptable limit suggested by the National Research Council, China and maximum $\mathrm{Cu}$ content $(30 \mathrm{mg} / \mathrm{kg}$ ) set by FAO/WHO (Chiu Wen Chen et al., 2012).

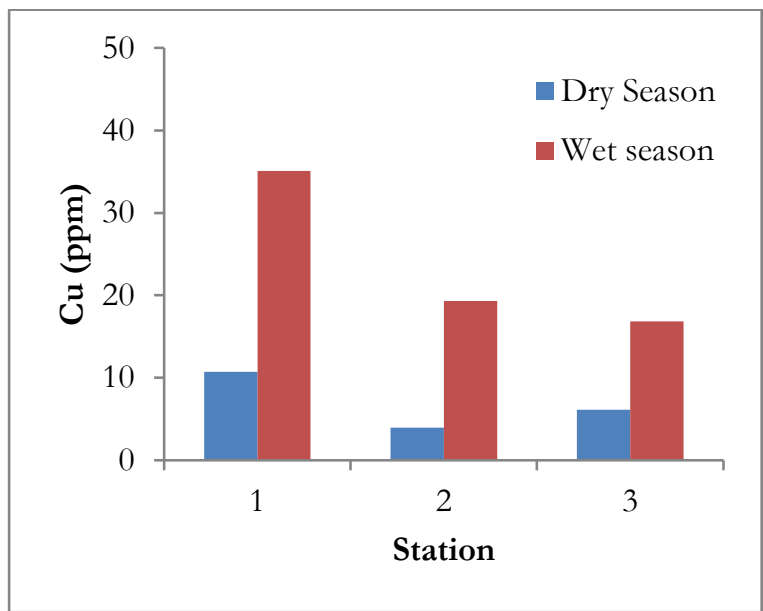

Figure 4. Copper Concentration in Guppy Fish.

The results also showed a significant $(\mathrm{p}<0.0001)$ variation in copper concentrations in all stations in both seasons. This indicated the lack of uniformity in their distribution at the stations and can be attributed to the different pollution levels at the stations and the differences in their chemistry in water. In addition, high rainfall during the wet season could have detached the organic and sediment bound copper making it more bioavailable for the fish intake.
The percentage recovery of copper in guppy fish is shown in Table 3 for all stations and in both seasons which is within the NIST certified acceptance/recovery range of $80 \%$ to 120\% (Huber, 2007; Schantz and Kucklick; Hokanson, 1994).

Table 3. Percent Recovery of Copper in Guppy Fish during Dry and Wet Season.

\begin{tabular}{ccc}
\hline Stations & Seasons & \% Cu Recovery \\
\hline \multirow{2}{*}{ Station 1 } & Dry & 108.24 \\
\cline { 2 - 3 } & Wet & 107.15 \\
\hline \multirow{2}{*}{ Station 2 } & Dry & 112.59 \\
\cline { 2 - 3 } & Wet & 113.36 \\
\hline \multirow{2}{*}{ Station 3 } & Dry & 108.00 \\
\cline { 2 - 3 } & Wet & 116.71 \\
\hline
\end{tabular}

Bioaccumulation Factor (BAF). BAFs were calculated using the mean metal concentration in fish and the corresponding metal concentrations for water, and sediments (Equation 1 and Equation 2). The bioaccumulation factors for copper with respect to water and sediments in both seasons are tabulated in Table 6 .

$$
\begin{array}{ll}
\mathrm{BAF}_{\mathrm{w}}=\frac{C_{\mathrm{fish}}}{C_{\text {water }}} & (\text { Equation 1) } \\
\mathrm{BAF}_{\mathrm{s}}=\frac{C_{\text {fish }}}{C_{\text {sediment }}} & \text { (Equation 2) }
\end{array}
$$

where $C_{\text {fish }}=$ metal concentration in fish, $C_{\text {water }}=$ metal concentration in water, and $C_{\text {sediment }}=$ metal concentration in sediment.

Table 4. BAF (L/kg) of Guppy Fish with respect to Water and Sediments.

\begin{tabular}{ccccc}
\hline \multirow{2}{*}{ Stations } & \multicolumn{2}{c}{ Dry Season } & \multicolumn{2}{c}{ Wet Season } \\
\cline { 2 - 5 } & $\mathbf{B A F}_{\mathbf{W}}$ & $\mathbf{B A F}_{\mathbf{S}}$ & $\mathbf{B A F}_{\mathbf{W}}$ & $\mathbf{B A F}_{\mathbf{S}}$ \\
\hline \multirow{2}{*}{1} & $1675 \pm$ & 0.1091 & $3735 \pm$ & $0.478 \pm$ \\
& 192 & \pm 0.019 & 267 & 0.067 \\
\hline \multirow{2}{*}{2} & $734 \pm$ & 0.0449 & $557 \pm$ & $0.220 \pm$ \\
& 293 & \pm 0.003 & 110 & 0.009 \\
\hline \multirow{2}{*}{3} & $411 \pm$ & 0.0616 & $815 \pm$ & $0.202 \pm$ \\
& 25 & \pm 0.001 & 110 & 0.003 \\
\hline
\end{tabular}

The bioaccumulation end point set by USEPA (2007) is 1000 to 5000 . The BAF of guppy for copper in water as shown in Table 4 ranges 
from 411-1675 and 557-3735 in dry and wet seasons, respectively. This means that guppy is capable of accumulating copper as depicted by the result in Stations 1.

In addition, Table 4 also shows that the guppy fish favors bioaccumulation through the water rather than in sediments. In fact, the BAF with respect to water positively correlated with the copper accumulation in fish $\left(\mathrm{r}^{2}=\right.$ 0.731 and 0.957 for both months, respectively) as shown in Figure 5. A similar study was conducted by Nussey et al. (1999) wherein the $\mathrm{Cu} \mathrm{BAF}$ values for water were higher than those for sediment in moggel, Labeo umbratus from Witbank Olifants River in South Africa suggesting that waterborne copper is the better predictor of copper concentration.
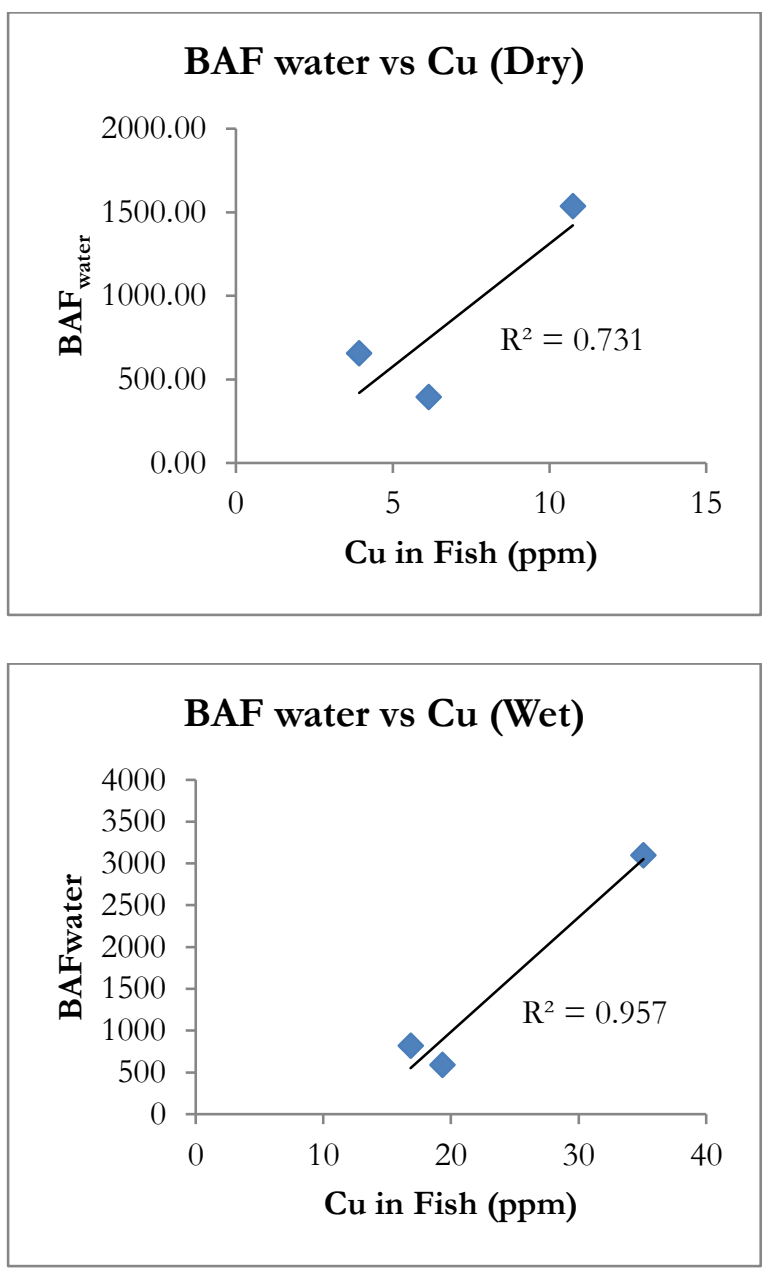

Figure 5. Correlation between $B A F$ in water and $\mathrm{Cu}$ Concentration.
Octanol-Water Partition Coefficient $\left(K_{o w}\right)$. The octanol-water partition coefficient of the river water samples are illustrated in Figure 6.

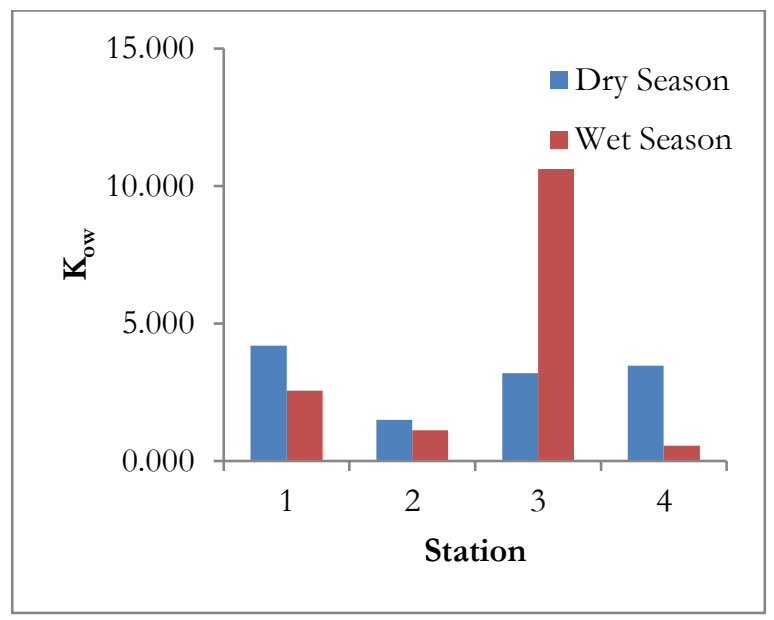

Figure 6. $K_{\text {ow }}$ of Copper Compounds in River Water.

The results showed that there is a significant difference per station in $K_{\text {ow }}$ values $(p<0.0001)$. However, there are no significant seasonal effects observed $(p=0.2054)$. In the dry period, the $K_{\text {ow }}$ in all stations are below 5 with station 1 having the highest value of 4.2. These values decreased during the wet season in Stations 1 and 2 but increased drastically in Station 3 by $65 \%$ from dry to wet season due presumably to the massive release of untreated effluents by surrounding industries during heavy downpour.

Based on the results of the $\mathrm{K}_{\mathrm{ow}}$, the dissolved copper in the Butuanon River for all sampling stations most likely exist in the hydrophilic phase. This confirms the report of the Fertilizer and Pesticide Authority (2010) that there is heavy use of fungicides with copper (II) hydroxide, copper thiodiazole and copper oxychloride as active ingredients in the Philippines and that there is indeed anthropogenic introduction of copper in the river.

Fourier Transform Infrared Spectroscopy Characterization. Figure 7 shows the chemical structure of thiodiazole-copper. Based on literature, the FTIR spectrum of thiodiazole showed some characteristic vibrational bands at 1588 and $1070 \mathrm{~cm}^{-1}$ assigned to $\mathrm{C}=\mathrm{N}$ and $\mathrm{N}-\mathrm{N}$ of the thiodiazole ring and $755 \mathrm{~cm}^{-1}$ for stretching of C-S bond 
(Bharty et al., 2012). Luo et al. (1994) also reported an IR spectra containing the thiodiazole derivative with IR bands at 750-, 1046- and $1577 \mathrm{~cm}^{-1}$.

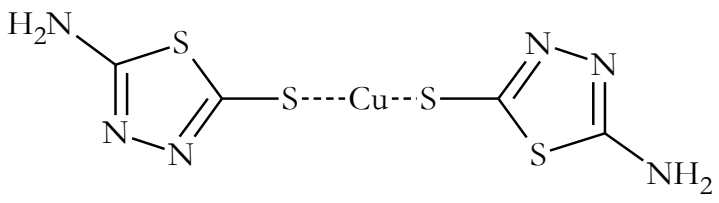

Figure 7. Structure of ThiodiazoleCopper.

This work shows traces of weak IR band at $1641 \mathrm{~cm}^{-1} \quad(\mathrm{n}=8)$, indicating a strong possibility of remnants of thiodiazole contaminants in the river water. At the outset of the research, this was invoked to be the pesticide used for mango trees which are present in the area of study. The weak C-S band at $668 \mathrm{~cm}^{-1}$ should theoretically shift to a higher frequency due to the increasing bond order of carbon-sulfur bond while the $\mathrm{C}=\mathrm{N}$ band is shifted to a lower frequency due perhaps to complexation with other available matrix (Haddad et al., 2013). The copper to sulfur band was not seen and could be an indication that sulfur is ionically bonded to $\mathrm{Cu}$ (II) in thiodiazole-copper complex and could have dissolve in water (Bharty et al., 2012). This result is in agreement with the findings of $\mathrm{K}_{\text {ow }}$ that copper in the river is indeed hydrophilic in nature.

Table 5. Summary of IR information from Literature and This Study.

\begin{tabular}{ccccc}
\hline IR Bands & $\begin{array}{c}\text { Bharty et al., } \\
(\mathbf{2 0 1 2 )}\end{array}$ & $\begin{array}{c}\text { Luo et al., } \\
\mathbf{( 1 9 9 4 )}\end{array}$ & $\begin{array}{c}\text { 20\% thiodiazole-copper } \\
\text { (Canete et al., 2013) }\end{array}$ & $\begin{array}{c}\text { River water } \\
\text { (Canete et al., 2013) }\end{array}$ \\
\hline$v_{\mathrm{C}-\mathrm{S}}$ & $755 \mathrm{~cm}^{-1}$ & $750 \mathrm{~cm}^{-1}$ & - & $668 \mathrm{~cm}^{-1}$, weak \\
\hline$v_{\text {thiodiazole }}$ & $1070 \mathrm{~cm}^{-1}$ & $1046 \mathrm{~cm}^{-1}$ & $1093 \mathrm{~cm}^{-1}$ & - \\
\hline$v_{\mathrm{C}=\mathrm{N}}$ & $1588 \mathrm{~cm}^{-1}$ & $1577 \mathrm{~cm}^{-1}$ & $1638 \mathrm{~cm}^{-1}$ & $1641 \mathrm{~cm}^{-1}$, weak \\
\hline
\end{tabular}

\section{CONCLUSION}

Overall, the copper levels in Butuanon River water samples vary between dry and wet seasons and are below the DENR standards. During wet season, station 2 provides the highest $\mathrm{Cu}$ level due probably to the three weather disturbances that could have washed away the copper containing waste of the nearby gasoline and carwash stations. Copper levels in sediment samples are less variable among stations and seasons but are consistently $2-5 x$ more than the tolerable limit set by DENR because contaminants that are continuously discharged at low levels will eventually accumulate and partition into the sediments. This further suggests that the sediments in the river can sequester metals, rendering them non-bioavailable due to precipitation of solids and sorption to iron phases.

\section{ACKNOWLEDGEMENTS}

The authors gratefully acknowledge the support provided by the following divisions of the University of San Carlos. The Department of Chemistry, the members of the Chemistry Analytical and EnvironmentaL Section II (ChAnELS II) namely Charmine I. Ronquillo, Leonila N. Adarna, Marilyn D. Piandong, Estherlina S. Ginete, Jill R. Quitayen, Rosemay N. Almirante, Ma. Charity Ruth U. Padayahag and Mari-Rose P. Dimataga for the assistance in the Butuanon River sampling, sample preparation and analysis, the Water Laboratory staff for the assistance in the AAS analysis, the USC-Office of Research for the financial support through Research Operational Mechanism (ROMe) and to the Kimika Writing Workshop held in Siliman University, Dumaguete City for the training provided.

\section{REFERENCES}

Abowei, JFN. The Condition Factor, LengthWeight relationship and Abundance of Elops senegalensis (Regan, 1909) from Nkoro River, Niger Delta, Nigeria. Advance J Food Sci Technol. 2010; 2(1):16-21.

Adeniyi, AA and Yusuf, KA. Determination of heavy metals in fish tissues, water and 
bottom sediments from Epe and Badagry Lagoons, Lagos, Nigeria. Environ Monitor Assess. 2007; 37:451-458.

Agah H, Leermakers M, Elskens M, Fatemi FMR, Baeyens W. Accumulation of trace metals in the muscles and the liver tissues of the five fish species from the Persian Gulf. Environ Monit Assess. 2009; 157:499-514.

Aksu Z, and Donmez G. Combined effects of sucrose and copper (II) ions on the growth and copper (II) bioaccumulation properties of Candida sp. J Chem Technol Biotechnol. 2000 Aug; 75(9):847-853.

American Public Health Association. Standard Methods for the Examination of Water and Wastewater. 20th ed. 1995.

ATSDR (Agency for Toxic Substances and Disease Registry). Toxicological profile for copper. U.S. Public Health Service, Atlanta, Georgia. TP-90-08. 1990; 142.

Bharty MK, Bharti A, Dani RK, Kushawaha SK, Dulare R, and Singh NK. Studies on novel $\mathrm{Cu}(\mathrm{II})$ complexes of 5-(4-hydroxyphenyl)-1,3,4-thiadiazole-2-thiol and 5thiophen-2-yl-3H-1,3,4-oxadiazole-2-thione:

Synthesis, spectral and structural characterization. Polyhedron. 2012 Jun; 41(1):52-60.

Binning K, Baried D. Survey of heavy metals in the sediment of the Swartkops River and Estuary, Port Elizabeth, South Africa. Water SA. 2001; 27(4):461-466.

Blasco J, Rubio JA, Forja J, Gomez-Parra A, Establier R. Heavy metals in some fishes of the muglidae family from salt-pounds of Codiz Baw SW Spain. Ecotix Environ Res. 1998, 1:71-77.

Bongo JP. Biocriteria and system analysis in the assessment of human impact in Butuanon River, Philippines; Its implication to sustainable watershed management: A case study of Butuanon River watershed, Cebu Province [master's thesis]. Lund, Sweden: Lund University; 1998.
Chen CW, Chen CF, Dong CD. Copper Contamination in the Sediments of Salt River Mouth, Taiwan. Energy Procedia. 2012; 16(B):901-906.

Davis A. Bioaccumulation of arsenic, chromium and lead in fish: constraints imposed by sediment geochemistry. Appl Geochem. 2006; 11(3):409-423.

Department of Environment and Natural Resources. 1990. DAO 90-34. Revised Water Usage and Classification Water Quality Criteria Amending Section Nos 68 and 69, Chapter III of the 1978 NPCC Rules. [accessed 2013 Mar 20]. Available from: http://www.emb.gov.ph/laws/water\%20quali ty $\% 20$ management/dao90-34.pdf.

Fertilizer and Pesticide Authority. List of registered agricultural pesticides as of January 2010.

Flifel I, Kadhim S. Synthesis and Chracterization of 1,3,4- oxadiazole derivatives with some new transition metal complexes. J Kerbala U. 2012; 10(3):197-209.

Food and Agriculture Organization/World Health Organization/FAO/WHO. List of maximum levels recommended for contaminants by the Joint FAO/WHO Codex Alimentarius Commission. Second Series. CAC/FAL, Rome: 1989, 3:1-8.

Gaur VK, Gupta SK, Pandey SD, Gopal K, Misra V. Distribution of heavy metals in sediment and water of river Gomti. Environ Monitor Assess. 2005; 10:419-433.

Haddad R, Yousif E, Ahmed A. Synthesis and characterization of transition metal complexes of 4-Amino-5-pyridyl-4H-1,2,4-triazole-3thiol. SpringerPlus. 2013; 2:510.

Hokanson GC. A life cycle approach to the validation of analytical methods during pharmaceutical product development, Part I: The initial validation process. Pharm Tech. 1994 Sep; 118-130. 
Huber L. Validation and quantification in Analytical Laboratories. Interpharm. New York, USA: Informa Healthcare; 2007.

Linnik PM, Zubenko B. Role of bottom sediments in the secondary pollution of aquatic environments by heavy-metal compounds. Lakes Reserv Res Manage. 2000; 5:11-15.

Malik N, Biswas AK, Qureshi TA, Borana K, Virha R. Bioaccumulation of heavy metals in fish tissues of a freshwater lake of Bhopal. Environ Monit Assess. 2010; 160:267-267.

Mandaue City Office of Sustainability and Environment [Internet]. Mandaue City: Mandaue City LGU; 2013 [accessed 2013 Apr 23]. Available from: http://www.mandauecity.gov.ph.

Mendoza CS, Suico ML. Trace metal concentrations in four selected rivers of Metro Cebu, Philippines: A baseline study. In: Proceedings of the Southwatch '95 Conference; 1995; University of San Carlos, Cebu City. p. 79-94.

Mendoza, C. Trace Metal Pollution in Selected Rivers of Metro Cebu, Philippines [master's thesis]. Cebu City: University of San Carlos; 1993.

Muego A. Butuanon River Rehabilitation: A Test Case for the Clean Water Act Implementation in Metro Cebu, Philippines. Regional Conference on Urban Water and Sanitation in Southeast Asian Cities; 2006; Vientiane, Lao PDR. p. 313-328.

Nazareno PAG. An Assessment of the Water Quality of Butuanon River (1996) in Mandaue City, Cebu. J Nat Sci. 2000; 5:8796.

Nussey G, Van Vuren JHJ, Preez HHD. Bioaccumulation of aluminium, copper, iron and zinc in the tissues of the moggel from Witbank Dam, Upper Olifants River Catchment (Mpumalanga). S Afr J Wildl Res. 1999; 29:130-144.
Oquiñena MK. Copper, Lead and Zinc Accumulation in Catfish and Earthworm from the Butuanon River, Metro Cebu, Philippines [master's thesis]. Cebu City: University of San Carlos; 2012.

PHILMINAQ. Mitigating Impact from Aquaculture in the Philippines. Water Quality Criteria and Standards for Freshwater and Marine Aquaculture. [accessed 2013 Mar 8]. Available from: http://www.aquaculture.asia/files/PMNQ\%2 0WQ\%20standard\%202.pdf.

Sanchez W, Palluel O, Meunier L, Coquery M. Porcher JM, Ait-Aissa S. Copper-induced oxidative stress in three-spined stickleback: relationship with hepatic metal levels. Environ Toxico Pharmacol. 2005; 19:177-183.

Savvaidis MN, Hughes RK, Poole ER. Copper biosorption by Pseudomonas cepacia and other strains. World J Microbiol Biotechnol. 2003; 19:117-121.

Schantz MM, Kucklick, JR. NIST Interlaboratory Analytical Comparison Study to Support Deepwater Horizon Natural Resource Damage Assessment: Description and Results for Marine Sediment QA10SED01. National Institute of Standards and Technology. Available from: http://www.nist.gov/mml/csd/upload/qa10s ed01-report.pdf.

Suico, MLS. Chemical Speciation of Copper, Chromium, Zinc and Lead in Sediments in the Butuanon River, Cebu [master's thesis]. Cebu City: University of San Carlos; 1997.

Turner A, Mawji E. Octanol-solubility of dissolved and particulate trace metals in contaminated rivers: implications for metal reactivity and availability. Environmental Pollution. 2004; 135:235-244.

Turner A, Williamson A. On the relationship between D-OW and K-OW in natural waters. Environ Sci Technol. 2005; 39(22):8719-8727.

US EPA. Aquatic life ambient freshwater quality criteria- copper. 2007 Revision, EPA- 
822-R-07-001 (CAS Registry Number 744050-8). US Environmental Protection Agency and Office of Water, Washington.
Zhang L, Wang J, Zhu G, Su L. Pubertal exposure to thiodiazole copper inhibits thyroid function in juvenile female rats. Exp Toxicol Pathol. 2010; 62(2):163-169. 